ARTICLE

https://doi.org/10.1038/s41467-019-08584-5

\title{
TRADD regulates perinatal development and adulthood survival in mice lacking RIPK1 and RIPK3
}

John P. Dowling ${ }^{1}$, Mohamed Alsabbagh ${ }^{1}$, Christina Del Casale, Zheng-Gang Liu ${ }^{1} \&$ Jianke Zhang ${ }^{1}$

TRADD is an adaptor for TNFR1-induced apoptosis and NFKB activation. However, TRADDdeficient mice undergo normal development and contain normal lymphoid populations, which contrasts with an embryonic defect in mice lacking FADD, the shared adaptor mediating apoptosis. Recent studies indicate FADD suppresses embryonic necroptosis mediated by RIPK1. TRADD was suggested to also mediate necroptosis. Here we report that targeting TRADD fails to rescue Fadd ${ }^{-1}$ - embryos from necroptosis, and ablation of TRADD rescues Ripk1 ${ }^{-/-}$mice from perinatal lethality when RIPK3-mediated necroptosis is disabled. The

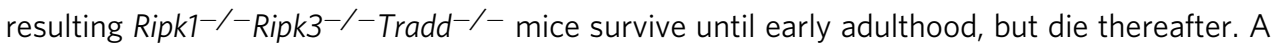
single allele of Tradd is optimal for survival of Ripk1 ${ }^{-/-}$Ripk3 ${ }^{-/-}$Tradd $^{+/}-$mice. We show that TRADD plays a more dominating role in NFKB-signaling than RIPK1. While RIPK1 protects thymocytes from TNF $\alpha$-induced apoptosis, TRADD promotes this process. The data demonstrate that TRADD is critical in perinatal and adult mice lacking RIPK1 and RIPK3, which has not been appreciated in prior studies.

\footnotetext{
${ }^{1}$ Department of Microbiology and Immunology, Sidney Kimmel Cancer Center, Thomas Jefferson University, 233 S. 10th St, Room 731, Philadelphia, PA 19107, USA. ${ }^{2}$ Center for Cancer Research, National Cancer Institute, 37 Convent Drive, Bethesda, MD 20892, USA. Correspondence and requests for materials should be addressed to J.Z. (email: jianke.zhang@jefferson.edu)
} 
rogrammed cell death (PCD) including apoptosis and necroptosis plays an important role during development ${ }^{1,2}$. In the immune system, PCD is required for homeostasis and suppression of autoimmunity ${ }^{3,4}$. Signaling through death receptors (DRs) of the TNFR1/Fas family can lead to $\mathrm{PCD}^{5}$. Apoptosis is mediated by the Fas associated death domain (FADD) adaptor protein, which recruits and activates caspase 8 to trigger the apoptotic program ${ }^{6-11}$. Apoptotic cells are engulfed by phagocytic cells, preventing spillage of intracellular contents, and thus limiting tissue damage and inflammation ${ }^{12-14}$. When apoptosis is blocked, necroptosis (or programmed necrosis) is initiated by receptor interacting protein kinase (RIPK) 1 and RIPK3 ${ }^{15-19}$. These two protein serine/threonine kinases interact with one another via their RIP homotypic interaction motif (RHIM). This results in phosphorylation of both RIPK1 and RIPK3 and recruitment/activation of the mixed lineage kinase domain like (MLKL) protein. Activated MLKL translocates to and disrupts the plasma membrane $e^{20,21}$. Loss of membrane integrity during necroptosis results in the release of cellular contents, leading to inflammatory responses ${ }^{22}$.

Although FADD and Caspase 8 were initially characterized as mediators of apoptotic cell death, genetic studies demonstrated these proteins paradoxically play a major role in preventing necroptotic cell death. Fadd ${ }^{-/-}$embryos and Casp $8^{-/-}$embryos die in utero and do not survive past embryonic day (E) $10.5^{23-25}$. Deletion of RIPK1 or RIPK3 corrects the embryonic defect in Fadd $^{-/-}$or Casp $8^{-/-}$mice ${ }^{26-28}$. Furthermore, deletion of RIPK3 completely restores normal development of Fadd ${ }^{-/-}$or Casp $8^{-/-}$ mice ${ }^{27-29}$. The resulting Casp $8^{-1-}$ Ripk $^{-1-}$ or Fadd ${ }^{-1-}$ Ripk3 $^{-1-}$ double knockout (DKO) mice develop progressive lymphadenopathy and splenomegaly, a hallmark of lymphoproliferative $(l p r)$ diseases.

Although RIPK1 (RIP or RIP1) was originally cloned as a Fas-interacting protein, deletion of RIPK1 results in perinatal lethality ${ }^{30}$, while Fas is dispensable in mouse development. Moreover, conditional deletion of RIPK1 specifically in T cells does not affect Fas-induced apoptosis ${ }^{31}$. Ripk $1^{-/-}$mice survive into late adulthood only when apoptosis is blocked by ablation of FADD or Caspase 8 and necroptosis is blocked by ablation of RIPK $3^{29,32-34}$. When only necroptosis is blocked, Ripk $1^{-/}$Ripk $3^{-/-}$mice die within several days after birth. TRADD is the primary adaptor for TNFR 1 and can induce both apoptosis and NFKB activation ${ }^{35,36}$. However, Tradd ${ }^{-/-}$ mice are viable and show no apparent developmental abnormality, despite defective TNFR1-mediated apoptosis and NF $\kappa$ B and MAPK signaling in Tradd ${ }^{-/}$cells $^{37-39}$. TRADD also mediates apoptosis and activation of NFKB and MAPK signaling through toll-like receptor (TLR) 3 and TLR4 as well as other DRs ${ }^{38,40}$. It has been suggested that TRADD, like RIPK1, can mediate necroptosis ${ }^{38}$. A better understanding of how TRADD fits into current models of cell death induction and regulation is essential to uncover a more complete picture of apoptotic and necroptotic signaling.

Here, we report an approach to investigate the physiological function of TRADD by employing unique animal models. The data indicates that TRADD plays no role in embryonic necroptosis in Fadd Fi- $^{-1}$ mice. However, the study uncovers a critical function for TRADD in mouse perinatal development as well as in adult mouse survival in the absence of RIPK1 and RIPK3. Moreover, TRADD is essential for lymphocyte survival in adult mice. The data show that TRADD mediates both apoptosis and NFKB activation. A single allele of TRADD is optimal for survival of of Ripk $1^{-/} R i p k 3^{-/-}$mice, indicating a Goldilocks principle.

\section{Results}

TRADD is dispensable for necroptosis in mouse embryos. In agreement with previous analysis of $C a s p 8^{-/-}$mice ${ }^{33}$, we found that lack of TNFa improves the survival of $\mathrm{Fadd}^{-1-}$ embryos (Supplementary Fig. 1), indicating that TNFR1-mediated necroptosis is partially responsible for embryonic death. TRADD is suggested to be the primary adaptor for TNFR1 and likely mediates both apoptosis and NFkB activation ${ }^{35,36}$. However, Tradd ${ }^{-/}$mice exhibit no apparent defect in development and contain a normal hematopoietic compartment ${ }^{37-39}$. TRADD was also suggested to mediate $\mathrm{TNF}$-induced necroptosis ${ }^{38}$. However, we found that absence of TRADD failed to rescue Fadd $^{-/}$embryos from death (Supplementary Fig. 2).

Ripk $1^{-/-}$or Ripk1 $1^{-/}$Fadd $d^{-/-}$mice undergo normal embryogenesis but die within one day of birth due to RIPK3-mediated necroptosis ${ }^{26,30}$. In contrast, Ripk $1^{-/-} \mathrm{Fadd}^{-/-} \mathrm{Ripk3}^{-/-}$mice are viable, indicating that RIPK3-mediated necroptosis is the leading cause of perinatal lethality in Ripk $^{-/-} \mathrm{Fadd}^{-1-}$ mice $\mathrm{C}^{29,32-34}$. Given possible functional redundancy between TRADD and FADD for apoptotic signaling and potential functional redundancy between TRADD and RIPK1 for NFKB signaling, we analyzed the impact of TRADD inactivation on the survival of Ripk $1^{-/-}$or Ripk1 $1^{-/}$Fadd ${ }^{-/-}$mice. As shown in Supplementary Fig. 3, all Ripk1 $1^{-/-}$Tradd $^{-/-}$mice died within one day of birth and were indistinguishable from Ripk $1^{-/}$mice, indicating that deletion of TRADD has no survival benefit in Ripk1-/- mice. In addition, intercross of Ripk1 $^{+/-} \mathrm{Fadd}^{+/-}$Tradd $^{-/-}$mice yielded no viable Ripk $1^{-/}$Fadd ${ }^{-/}$Tradd ${ }^{-/}$mice at weaning age (Supplementary Fig. 3a, c), unlike the normal postnatal development seen in Ripk $1^{-/-}$Ripk $3^{-/}$Fadd ${ }^{-/}$mice described in prior studies ${ }^{29,32-34}$. In total, the data indicate that TRADD does not mediate lethal necroptosis in Fadd ${ }^{-/-}$embryos or in Ripk1 ${ }^{-/-}$ and Ripk1 ${ }^{-/-}$Fadd $^{-I-}$ neonates.

TRADD deletion in Ripk $^{-/-} \boldsymbol{R i p k 3}^{-/-}$mice. We performed further analysis to evaluate the in vivo function of TRADD in apoptosis using $R i p k 1^{-/}$Ripk $3^{-/-}$mice, in which necroptosis is blocked. To this end, viable Ripk $1^{+/-}$Ripk $3^{-/-}$Tradd ${ }^{-/-}$mice were generated and intercrossed. Weaning age Ripk $1^{-/}{ }^{-}$Ripk3 $3^{-/-}$Tradd $^{-/-}$triple knockout (TKO) mice were detected at expected Mendelian frequencies (Fig. 1a), which is in sharp contrast to the perinatal lethality exhibited by Ripk $1^{-1-}$ Ripk $3^{-1-}$ neonates (Fig. 1b). This data provides in vivo evidence that a TRADD-mediated signaling pathway blocks perinatal mouse development in the absence of RIPK1 and RIPK3. However, Ripk1 $1^{-/}$Ripk3 $3^{-/-}$Tradd $^{-/-}$mice fail to thrive in adulthood and progressively lose weight over a period of several weeks (Fig. 1b-d). Histological analysis of the Ripk $1^{-/}$Ripk $^{-/-}$Tradd ${ }^{-/-}$large intestine showed an obvious loss of goblet cells and massive immune cell infiltration in the TKO intestine (Fig. 1e). In addition, elevated levels of activated caspase 3 (CC3) were evident in the large intestine of the Ripk $1^{-/-}$Ripk $^{-/-}$Tradd $^{-/-}$TKO mice, when compared to wildtype control mice (Fig. 1e). Among the mice analyzed, the longest survival is postnatal day $(\mathrm{P}) 78$, when the moribund animal was euthanized (Fig. 1b).

To understand the role of TRADD in adult mice further, analysis was performed with intercross of triple heterozygous (THZ) Ripk $1^{+/-}$Ripk $3^{+/-}$Tradd ${ }^{+/-}$mutant mice. Interestingly, heterozygosity of both RIPK3 and TRADD was sufficient for Ripk $1^{-/-}$mice to survive from birth to weaning age (Fig. 2a). Among the resulting Ripk $1^{-/-}$Ripk $3^{+/-}$Tradd ${ }^{+/}-$mutant mice analyzed, survival up to P85 was observed, when the moribund 
a

\begin{tabular}{cccccc}
\multicolumn{7}{c}{ Offspring of Ripk1+- Ripk3 $^{-/-}$Tradd $^{-/-}$intercrosses } \\
\hline \multirow{3}{*}{ Genotype } & Ripk1 & $+/$ & $+/-$ & $-/-$ & Total \\
& Ripk3 & $-/-$ & $-/-$ & $-/-$ & \\
& Tradd & $-/-$ & $-/-$ & $-/-$ & \\
\hline \multirow{2}{*}{$\begin{array}{c}\text { At weaning } \\
\text { age }\end{array}$} & Actual & 16 & 28 & 12 & 56 \\
& Expected & 16 & 32 & 16 & 64 \\
\hline
\end{tabular}

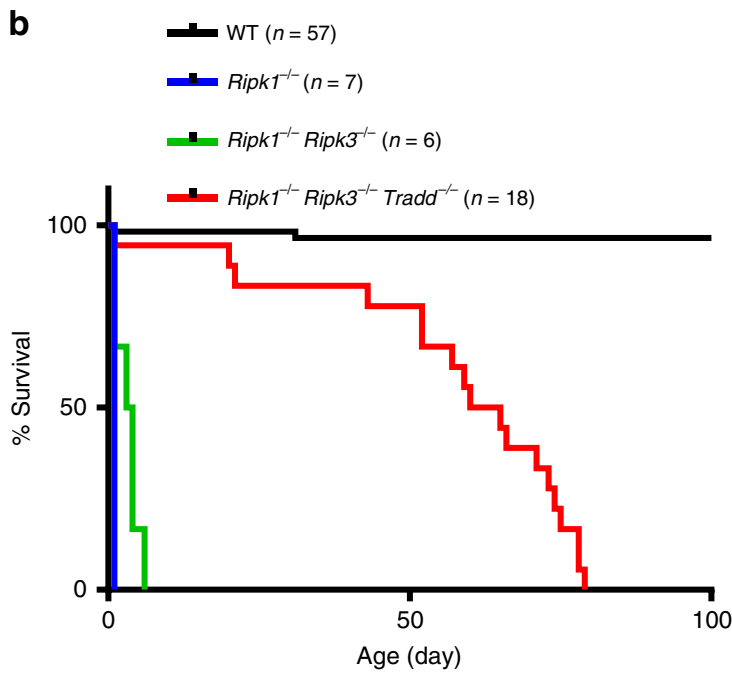

C

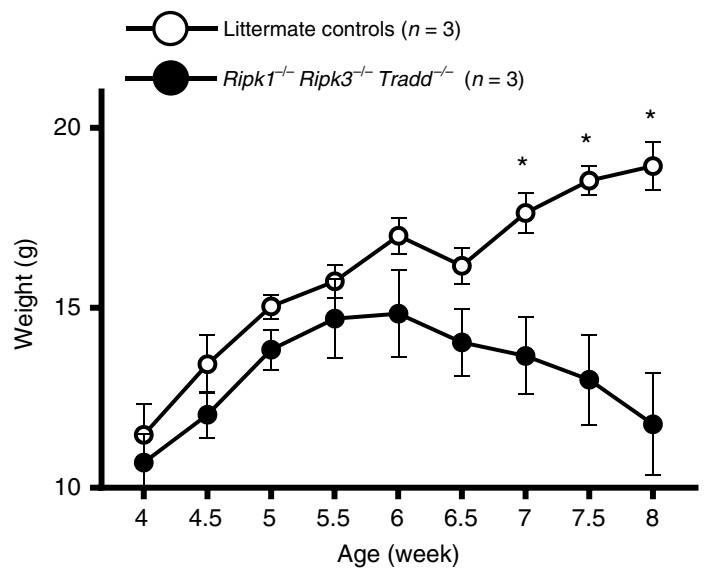

d
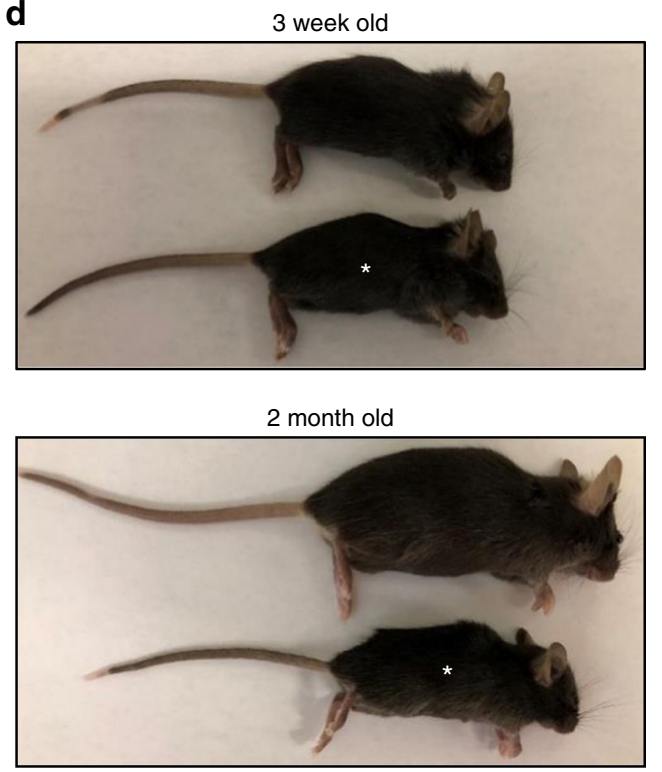

e
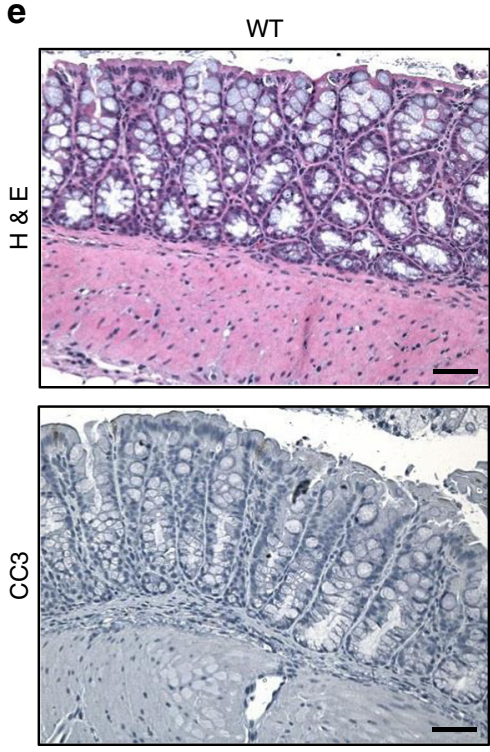
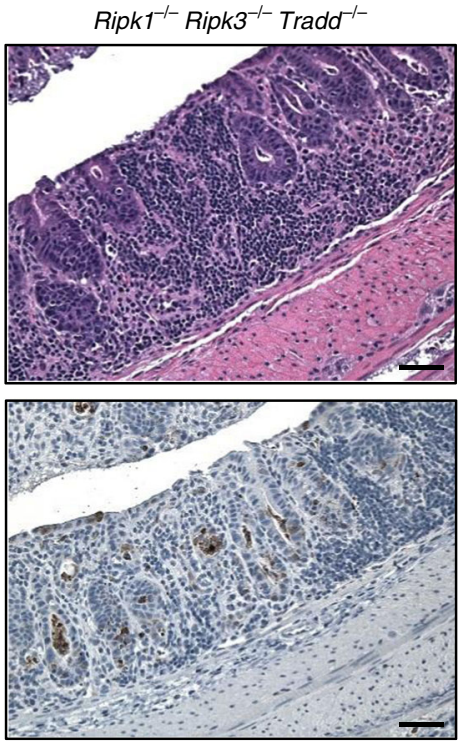

Fig. 1 Deletion of TRADD improves the survival of Ripk1 $1^{-/}$Ripk3 ${ }^{-/-}$into young adulthood. a Actual and expected frequencies of pups at weaning age from intercrosses of Ripk $1^{+/}$-Ripk3 ${ }^{-/-}$Tradd ${ }^{-/}-$mice. Chi square analysis shows no significant difference between actual and expected $(p=0.472)$.

b Kaplan-Meier plot showing survival of mice of indicated genotypes. Logrank tests shows a significant increase in survival of Ripk $1^{-/-}$Ripk3 ${ }^{-/-}$Tradd ${ }^{-/-}$ mice, compared to Ripk1 ${ }^{-/}$Ripk3 ${ }^{-/}$mice $(p<0.0001)$ but significantly less than WT mice $(p<0.0001)$. c Weights of Ripk1 $1^{-/-}$Ripk3 $3^{-/-}$Tradd ${ }^{-/}$mice and littermate controls over time presented as mean \pm SEM, ${ }^{\star} p<0.05$ as determined by Student's $t$ test. d Three week old and two month old Ripk ${ }^{-} /-$ Ripk3 ${ }^{-/}-$Tradd $^{-/-}$mice $\left(^{\star}\right)$ with littermate controls ( $n=5$ independent experiments). e Hematoxylin and eosin (H\&E) and cleaved caspase 3 (CC3) staining of the large intestine of indicated genotypes $(n=3$ independent experiments). Scale bars are $50 \mu \mathrm{m}$

animal was euthanized (Fig. 2b). Remarkably, retaining just one wild-type allele of the Tradd gene provides better survival than two wild-type alleles (Tradd ${ }^{+/+}$) or two KO alleles (Tradd ${ }^{-/-}$) for adult Ripk $1^{-/-}$Ripk $3^{-/-}$mice (Fig. 2a-c). Weaning age Ripk1 $1^{-/}$Ripk $^{-/-}$Tradd $^{+/-}$mice are found at expected
Mendelian frequencies (Fig. 2a) and survived normally throughout adulthood (Fig. 2b), in contrast to Ripk1-/-Ripk3-/Tradd $^{-/}$mice, which die in early adulthood (Fig. 1b). Ripk1 $1^{-1-}$ Ripk3 $^{-/-}$Tradd $^{+/-}$mice are indistinguishable in appearance and weight from wild-type controls (Fig. 2c, d), and are fertile. In 
a Genetic analysis of Ripk $1^{+/-}$Ripk3 $^{+/-}$Tradd $^{+/-}$intercrosses

\begin{tabular}{|c|c|c|c|c|c|c|c|c|c|}
\hline Genotype & $\begin{array}{l}\text { Ripk1 } \\
\text { Ripk3 } \\
\text { Tradd }\end{array}$ & $\begin{array}{c}+/+,+/- \\
+/+,+/-,-/- \\
+/+,+/-,-/-\end{array}$ & 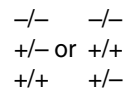 & $\begin{array}{l}-1- \\
+/- \\
+/-\end{array}$ & $\begin{array}{ll}-/ & -/- \\
-/- & \text { or } \\
+/+ \\
+/+ & -/-\end{array}$ & $\begin{array}{l}-/- \\
+/- \\
-/-\end{array}$ & $\begin{array}{l}-1- \\
-1- \\
+/-\end{array}$ & $\begin{array}{l}-1- \\
-1- \\
-1-\end{array}$ & Total \\
\hline At weaning & Actual & 100 & 0 & 4 & 0 & 3 & 6 & 3 & 116 \\
\hline
\end{tabular}
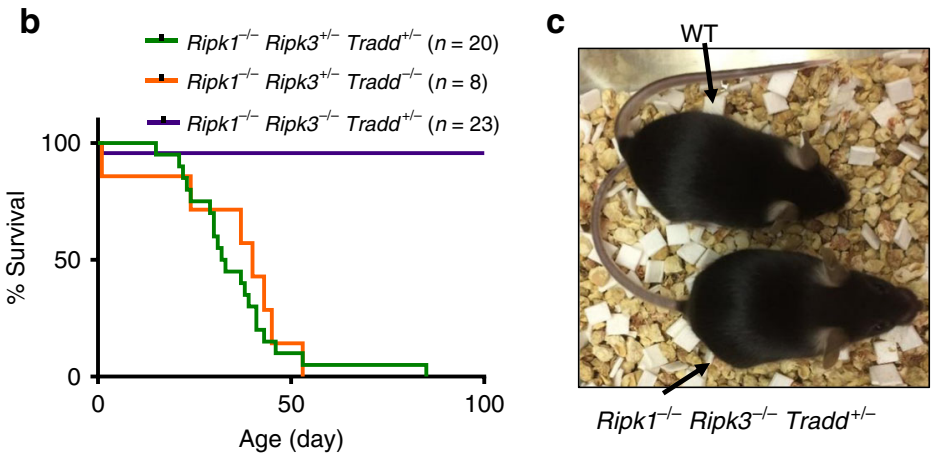

d

e

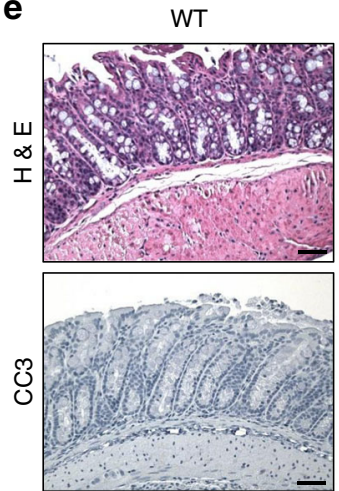

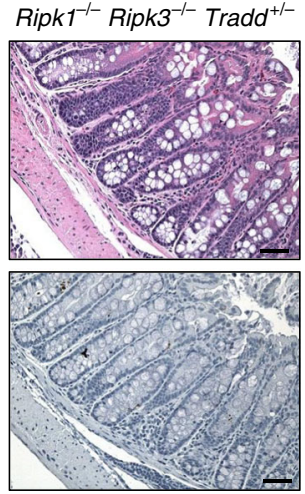

Fig. 2 Haplosufficiency of TRADD rescues the lethality of Ripk1-/-Ripk3-/- mice. a Expected and actual frequencies of pups at weaning age from a triple heterozygous cross of Ripk $1^{+/-}$Ripk3 ${ }^{+/-}$Tradd ${ }^{+/-}$mice. $\mathbf{b}$ Kaplan-Meier plot showing survival of mice of indicated genotypes. Logrank tests showed

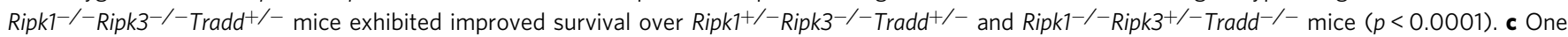
month old mice of indicated genotypes ( $n=5$ independent experiments). $\mathbf{d}$ Weights of Ripk ${ }^{-} /-$Ripk $3^{-} /-$Tradd ${ }^{+} /-$mice and littermate controls over time presented as mean \pm SEM. $t$ test shows no significant difference between groups. e H\&E and cleaved caspase 3 (CC3) staining of the large intestine of indicated genotypes ( $n=3$ independent experiments). Scale bars are $50 \mu \mathrm{m}$

addition, Ripk1 $1^{-/-}$Ripk $3^{-/-}$Tradd ${ }^{+/-}$mice were similar to wildtype mice with minimal levels of activated caspase 3 in the large intestine (Fig. 2e), unlike Ripk $1^{-/}$Ripk $3^{-1-}$ Tradd $^{-1-}$ mice, which show greatly elevated active caspase 3 levels in the large intestine (Fig. 1e). Ripk1 $1^{-/}$Ripk3 $^{-/-}$Tradd ${ }^{+/-}$ mice older than 6 months display no enlargement of the lymphoid organs (Supplementary Fig. 4a) nor presence of the abnormal $\mathrm{CD}^{+} \mathrm{B} 220^{+}$population (Supplementary Fig. $4 \mathrm{~b}$ ), the typical symptoms of lymphoproliferative $(l p r)$ disease present in $\mathrm{Fas}^{-1-}$ mice. This contrasts the severe lpr phenotype in Fadd $^{-/-}$Ripk3 $^{-/-}$or Fadd ${ }^{-/}$Ripk3 ${ }^{-/}$Ripk1 $1^{-/-}$mice shown

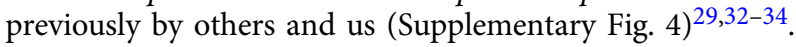

A $\mathrm{T}$ cell defect in adult $\operatorname{Ripk1}^{-/-} \mathrm{Ripk3}^{-/-}$Tradd $^{-/-}$mice. Tradd $d^{-1-}$ mice contain normal lymphocyte populations, indicating a dispensable role for TRADD in lymphopoiesis ${ }^{38}$. Here, we show that in young adult mice (7-8 week old), the lymphoid organs of Ripk $1^{-/}$Ripk $3^{-/-}$Tradd $^{+/-}$mice are indistinguishable from wild-type controls despite a reduction of TRADD protein levels and the absence of RIPK1 and RIPK3 (Supplementary Fig. 5). However, deletion of both TRADD alleles results in an

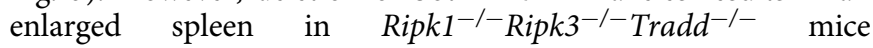

(Supplementary Fig. 5b, c). Flow cytometric analysis indicates that the spleen of Ripk $1^{-/}$Ripk $3^{-/-}$Tradd ${ }^{-1-}$ mice contain an increased $\mathrm{Mac}^{+} \mathrm{Gr}^{+}$myeloid cell population (Supplementary Fig. 6,a). The thymus is significantly reduced by size and weight (Supplementary Fig. 5b, c) and thymic cellularity was also greatly decreased compared with WT controls (Supplementary Fig. 5d). Flow cytometric analysis showed a major reduction of the immature $\mathrm{CD}^{+} \mathrm{CD}^{+}$double positive population in the thymus

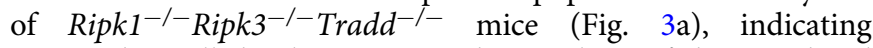
impaired $\mathrm{T}$ cell development. Further analysis of the peripheral lymphoid organs showed that the spleen and lymph nodes exhibited a marked reduction of $\mathrm{CD}^{+} \mathrm{T}$ cell numbers of both $\mathrm{CD}^{+}$and $\mathrm{CD}^{+}$lineages (Fig. $3 \mathrm{a}-\mathrm{c}$ ), resulting in a dramatic $\mathrm{T}$ lymphopenia. In addition, Ripk $1^{-1-}$ Ripk $3^{-1-}$ Tradd $^{-1-}$ mice have significantly reduced bone marrow cell numbers (Supplementary Fig. 5d). Flow cytometric analysis of the $B$ lineage showed a decrease in $\mathrm{B}_{2} 20^{\mathrm{lo}} \mathrm{IgM}^{-}$pro/pre $\mathrm{B}$ cells in the bone marrow and no apparent defect in the periphery in Ripk1 $1^{-/}$Ripk3 $^{-/-}$Tradd $^{-/-}$mice (Supplementary Fig. 6b, c).

TRADD mediates apoptosis in $\mathbf{T}$ cells. Given the pronounced defect in $\mathrm{T}$ cell development in the thymus and T-lymphopenia in 
a

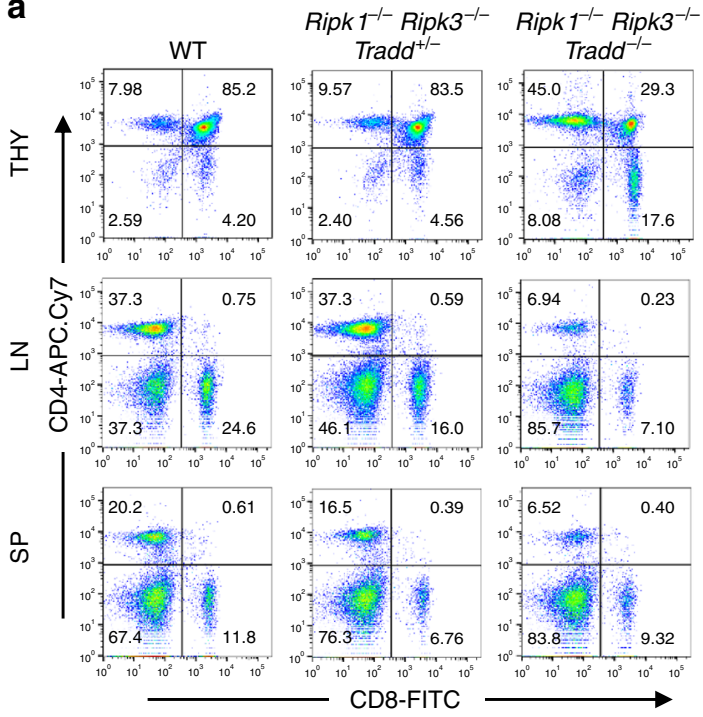

b
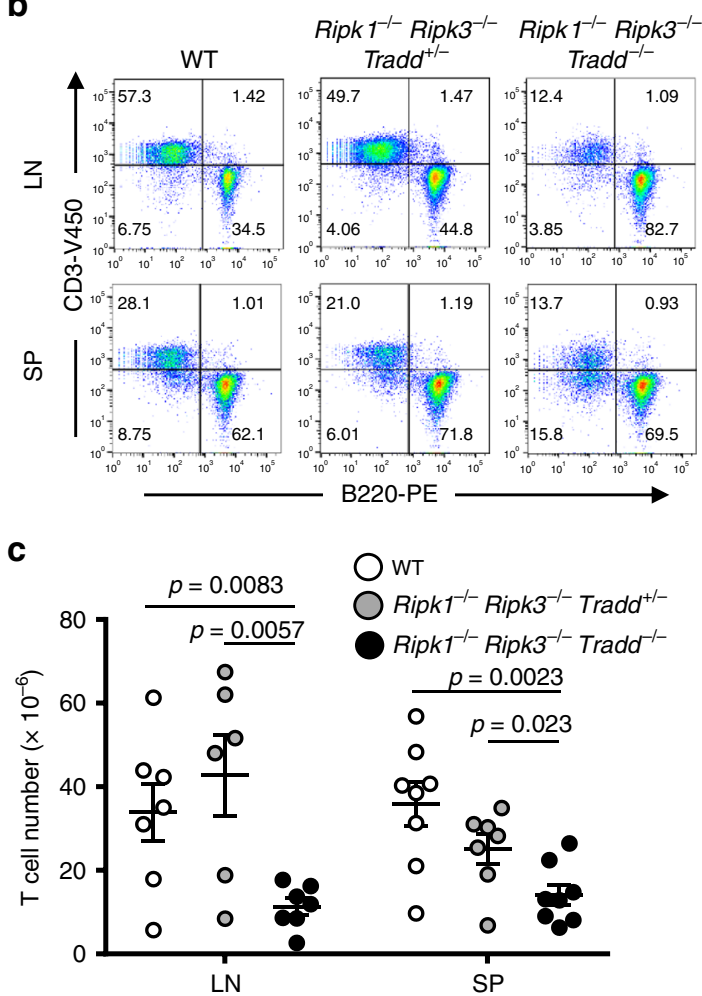

Fig. 3 Ripk1 ${ }^{-/-}$Ripk3 ${ }^{-/}{ }^{-}$radd $^{-/-}$mice display impaired T cell development and T lymphopenia in young adulthood. a, b Representative two-color flow cytometric plots showing $\mathbf{a} \mathrm{CD}^{+}$and $\mathrm{CD} 8^{+} \mathrm{T}$ cells in the lymph nodes, spleen, and thymus and $\mathbf{b} \mathrm{T}$ cells $\left(\mathrm{CD} 3^{+}\right)$and $\mathrm{B}$ cells $\left(\mathrm{B} 22 \mathrm{O}^{+}\right)$in the lymph nodes and spleen ( $n=8$ independent experiments). $\mathbf{c} \mathrm{CD}^{+}$T cell numbers in the lymphoid organs of 7-8 week old mice of indicated genotypes ( $n=7$

independent experiments). All graphs presented as mean \pm SEM

the periphery in Ripk1 $1^{-/}$Ripk3 $3^{-/}$Tradd ${ }^{-/}$mice, we performed analysis of thymocytes for their ability to respond to stimuli through the DRs. WT, Ripk $1^{-/-}$Ripk $^{-/-}$Tradd $^{+/-}$, and Ripk1 $1^{-/}$Ripk3 $^{-/-}$Tradd $^{-1-}$ thymocytes were similarly sensitive to Fas-induced cell death (Supplementary Fig. 7a). By contrast, Ripk1 ${ }^{-/}$Ripk3 $^{-/-}$Tradd $^{+/-}$thymocytes readily undergo TNFainduced cell death (Fig. 4a). However, wild-type and Ripk $1^{-/}$Ripk3 $3^{-1-}$ Tradd $^{-/-}$thymocytes were equally resistant to TNFa. This is also true of mature peripheral $\mathrm{T}$ cells from the genotypes tested, which all undergo Fas-mediated apoptosis but only Ripk $1^{-/}$Ripk $3^{-/-}$Tradd ${ }^{+/-}$cells are sensitive to TNFainduced cell death (Supplementary Fig. 7b, c). Ripk1-/Ripk3 ${ }^{-/-}$Tradd ${ }^{+/-}$thymocytes are also sensitive to cell death induced by human TNFa, which binds to TNFR1 and not TNFR2 ${ }^{41}$ (Supplementary Fig. 7d). In addition, blocking of TNFR1, but not TNFR2, largely prevents this cell death (Supplementary Fig. 7e). These data indicate that lack of RIPK1 sensitizes thymocytes to TRADD-mediated apoptosis induced by TNFa through TNFR1.

We also performed analysis of TCR-induced responses. The data show an increased $\mathrm{PI}^{+}$population in Ripk1-/Ripk3-/-Tradd ${ }^{-1-}$ TKO T cells after $48 \mathrm{~h}$ TCR stimulation, than wild type control $\mathrm{T}$ cells (Fig. 4b). Cell division barely occurred in Ripk $1^{-/}$Ripk $3^{-/-}$Tradd ${ }^{-/}$TKO T cells stimulated through the TCR for $48 \mathrm{~h}$, as compared to wild-type control $\mathrm{T}$ cells. A single wild-type allele of TRADD provided improvement, as indicated by an intermediate phenotype in Ripk $1^{-/}$Ripk $^{-/-}$Tradd $^{+/-} \mathrm{T}$ cells, which displayed moderately decreased cell death and moderately increased proliferation, when compared to Ripk1 $1^{-/}$Ripk3 ${ }^{-/-}$Tradd ${ }^{-/}$TKO T cells (Fig. 4b). The defect in Ripk $^{-/-}$Ripk3 $3^{-/}$Tradd ${ }^{+/}-\mathrm{T}$ cells remains significant when compared with wild-type $\mathrm{T}$ cells.
To determine the nature of the TCR-induced cell death, T cells were treated with the wide-spectrum caspase inhibitor zVADfmk. This treatment rescued Ripk $1^{-/}$Ripk $3^{-/-}$Tradd ${ }^{-/}-\mathrm{T}$ cells from death during TCR stimulation (Fig. 4b). Moreover, zVAD treatments greatly improved TCR-induced cell division/proliferation in Ripk1 $1^{-1-}$ Ripk $^{-/-}$Tradd $^{-1-} \mathrm{T}$ cells as well as in Ripk $1^{-1-}$ Ripk $3^{-/-}$Tradd ${ }^{+/-} \mathrm{T}$ cells (Fig. 4b). Therefore, these mutant TKO T cells undergo enhanced apoptosis in response to TCR stimulation, despite a resistance to TNFa-induced apoptosis (Fig. 4a). To understand further the enhanced apoptosis phenotype, western blotting analysis was performed to examine anti-apoptotic proteins. Freshly isolated resting $R i p k 1^{-/-}$ Ripk3 ${ }^{-/}-$Tradd $^{-/}-\mathrm{T}$ cells have lower expression of cFLIP than in Ripk $1^{-/}$Ripk3 $3^{-/-}$Tradd ${ }^{+/}$and WT $\mathrm{T}$ cells (Fig. 4c). In contrast, $\mathrm{Bcl}-\mathrm{X}_{\mathrm{L}}$ is barely detectable in freshly isolated resting $\mathrm{T}$ cells, and is highly induced at $16 \mathrm{~h}$ post stimulation with antiCD3/CD28 antibodies (Fig. 4c). This TCR-induced Bcl-X $\mathrm{X}_{\mathrm{L}}$

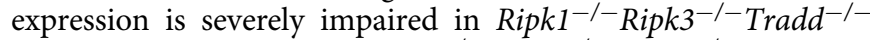
$\mathrm{T}$ cells, as compared to Ripk1 $1^{-/-}$Ripk3 $^{-/-}$Tradd $^{+/-}$and WT $\mathrm{T}$ cells (Fig. 4c). These two proteins are critical for $\mathrm{T}$ cell survival by inhibiting apoptosis and are target genes of the pro-survival NFkB pathway. Ripk $1^{-/}$Ripk3 $3^{-/-}$Tradd ${ }^{-1-}$ T cells do appear to have reduced NFKB signaling, as indicated by reduced phosphorylation of NFkB p65 (Supplementary Fig. 8a). Ripk1-/Ripk3 ${ }^{-/-}$Tradd $^{-1-}$ T cells also display elevated caspase activation upon stimulation (Supplementary Fig. 8b). Similarly, significantly elevated active caspase 3 levels were present in Ripk1-/Ripk $3^{-/-}$Tradd $^{-/}$large intestine (Supplementary Fig. 8c). In total, a single wild-type Tradd allele is advantageous for Ripk $1^{-/-}$Ripk $3^{-/-} \mathrm{T}$ cell survival after stimulation through the TCR. Moreover, the data clearly indicate that TRADD has a dual function in $\mathrm{T}$ cells. 
a

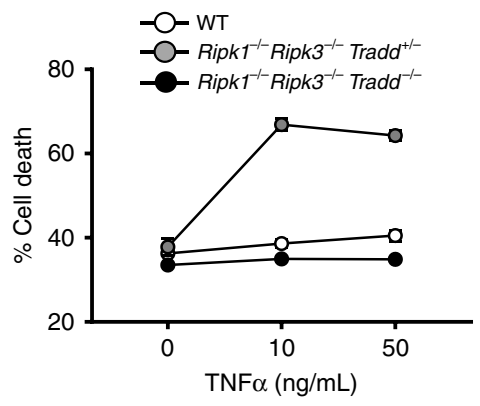

C
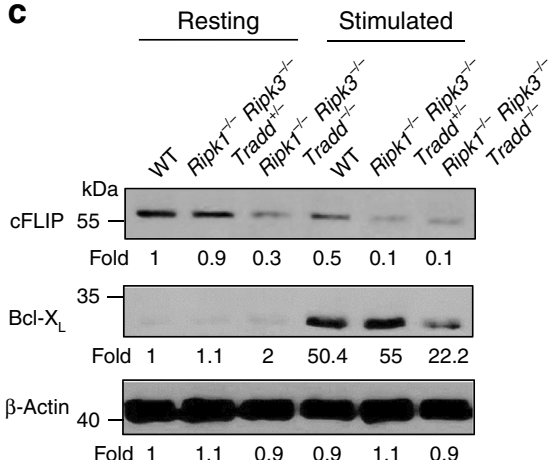

b
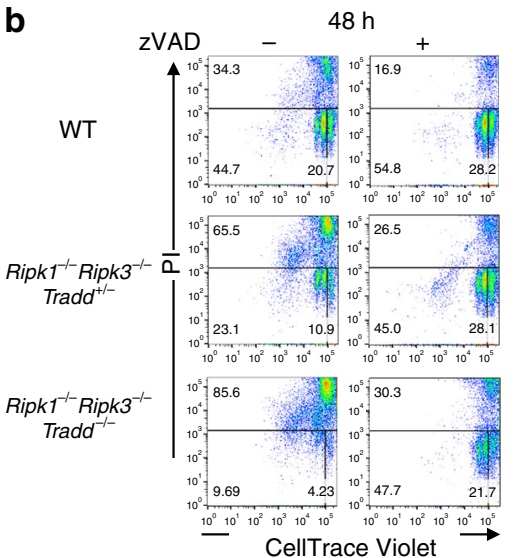

d

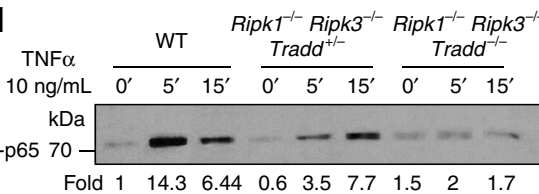

p65 70

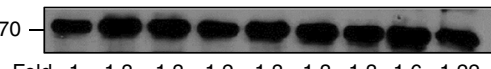

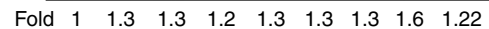

$\beta$-Actin

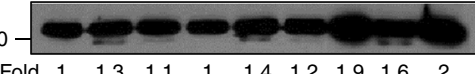

e

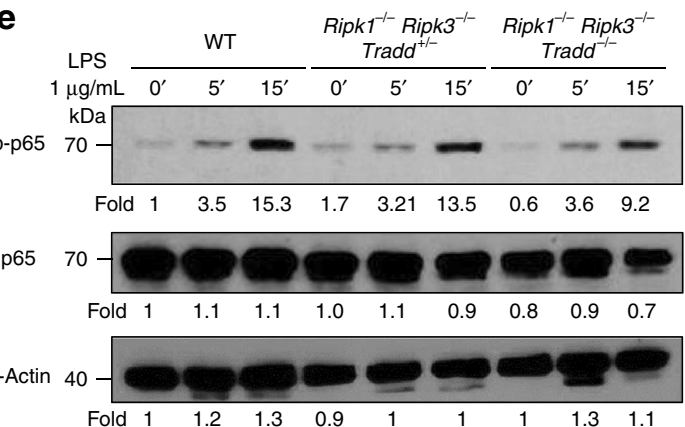

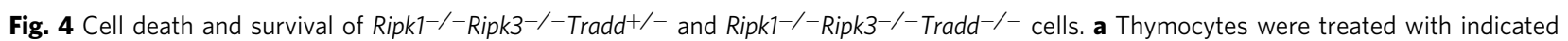
concentrations of TNF $\alpha$ for $16 \mathrm{~h}$ with $30 \mu \mathrm{g} / \mathrm{mL}$ cycloheximide. After addition of $1 \mu \mathrm{g} / \mathrm{mL}$ propidium iodide (PI), dead cells $\left(\mathrm{PI}^{+}\right)$were determined by flow cytometry (performed in triplicate, presented as mean $\pm \mathrm{SEM}, n=3$ independent experiments). $\mathbf{b}$ Mature T cells were isolated from the lymph nodes and spleen, labeled with CellTrace Violet (Invitrogen), pretreated for $1 \mathrm{~h}$ with or without $50 \mu \mathrm{M}$ zVAD-fmk, and stimulated with $5 \mu \mathrm{g} / \mathrm{mL} \alpha \mathrm{CD} 3$ and $1 \mu \mathrm{g} / \mathrm{mL}$ $\alpha C D 28$. At 48 h, cells were harvested, stained with PI, and analyzed by two-color flow cytometry ( $n=3$ independent experiments). $\mathbf{c}$ Western blot of cFLIP, $\mathrm{BCl}-\mathrm{X}_{\mathrm{L}}$, and $\beta$-Actin in resting and stimulated mature T cells of indicated genotypes. Representative of three independent experiments. $\mathbf{d}$, e Western blots of p65 phosphorylation, total p65, and $\beta$-Actin after stimulation of fibroblasts with $\mathbf{d} 10 \mathrm{ng} / \mathrm{mL} \mathrm{TNF} \alpha(n=5 \mathrm{independent} \mathrm{experiments)} \mathrm{or} \mathrm{e} 1 \mu \mathrm{g} / \mathrm{mL} \mathrm{LPS}$ ( $n=$ 3 independent experiments). Numbers under each gel indicate fold changes of signals for each lane

A critical role for TRADD in TNFa-mediated NFKB signaling. The ability to activate this pathway by TNFa was analyzed by examining induction of phosphorylation of NFkB p65 (p-p65) in mouse fibroblasts. In WT fibroblasts rapid phosphorylation of p65 was induced within $5 \mathrm{~min}$ of TNFa treatment, but NFkB activation is completely blocked in Ripk1 $1^{-1-}$ Ripk3 $^{-/-}$Tradd $^{-/-}$ fibroblasts (Fig. 4d). A single allele of TRADD in Ripk1-/Ripk3-/-Tradd ${ }^{+/-}$fibroblasts results in an intermediate phenotype, that is a delayed activation of the NFKB pathway (Fig. $4 \mathrm{~d}$ ). We treated wild-type and mutant fibroblasts with LPS and analyzed NFkB induction. Ripk1 $1^{-/}$Ripk3 ${ }^{-/-}$Tradd $^{-/}$fibroblasts were capable of phosphorylating NFKB, albeit at slightly lower levels than WT fibroblasts (Fig. 4e). In total, TRADD is essential for TNFa-induced NFkB activation in Ripk $1^{-/}$Ripk $3^{-/-}$fibroblasts, but is dispensable for LPS-induced NFkB activation.
It is possible that the loss of DP thymocytes in Ripk1-/Ripk3 $^{-/-}$Tradd $^{-1-}$ (Fig. 3a) is secondary to the wasting disease (Fig. 1c). To this end, we analyzed younger mice (3 week old) which have no apparent wasting disease. The lymphoid organs of young Ripk1 $1^{-/}$Ripk3 $3^{-/}$Tradd ${ }^{-/}$mice are normal, as compared to WT controls (Supplementary Fig. 9a). There was no obvious defect in the thymus, and mature $\mathrm{T}$ cell numbers in lymph nodes was reduced in Ripk $1^{-/}$Ripk $3^{-/-}$Tradd ${ }^{-/}$mice (Supplementary Fig. 9b, c). Thymocytes isolated from 3 week old Ripk1 $1^{-/}$Ripk $^{-/-}$Tradd $^{-/-}$mice are also resistant to TNFa-

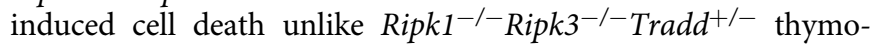
cytes (Supplementary Fig. 10), similar to the result in Fig. 4a. We performed analysis of NFKB target genes in TNFa-treated fibroblasts, and the data indicates impaired $\mathrm{NF \kappa B}$ signaling in TKO cells. TNFAIP3 (or A20), an NFkB target gene, is 

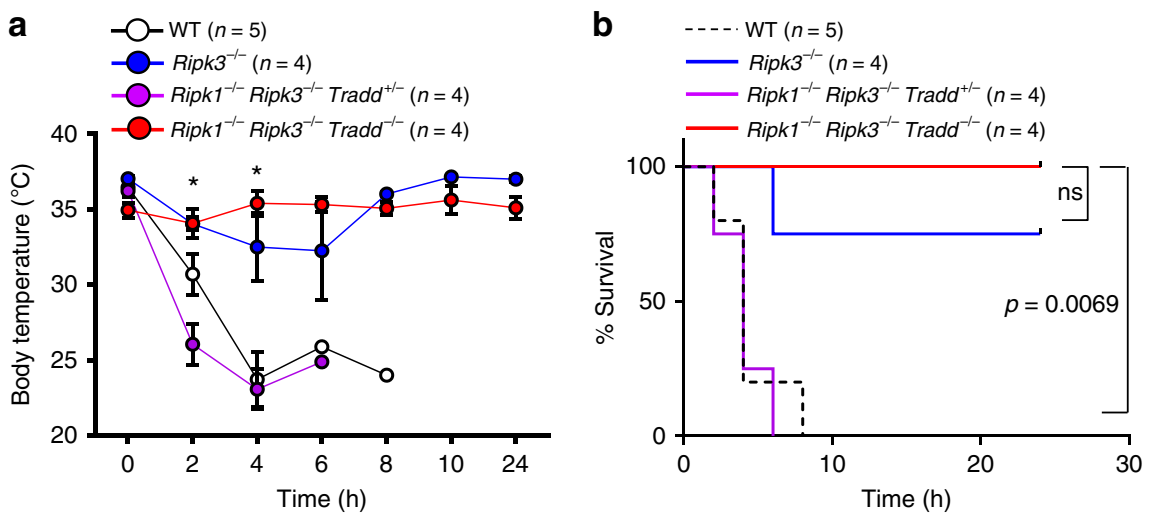

Fig. 5 Ripk1 $1^{-/}$Ripk3 ${ }^{-/-}$Tradd $^{+/} /-$mice succumb to lethal TNF $\alpha$-induced shock. a Body temperatures of mice of indicated genotypes over time. $t$ tests show

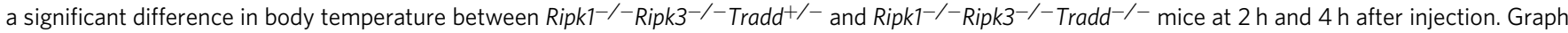
presented as mean \pm SEM. ${ }^{*} p<0.05$ as determined by Student's $t$ test. b Kaplan-Meier plot showing survival of mice of indicated genotypes. Logrank test shows a significant difference in survival between Ripk $1^{-/-}$Ripk3 $^{-/}{ }^{-}$Tradd $^{+/-}$and Ripk $1^{-/}{ }^{-}$Ripk3 $^{-/-}$Tradd $^{-/-}$mice $(p=0.0069)$

downregulated in Ripk1 $1^{-/}$Ripk3 $3^{-/-}$Tradd $^{-/-}$(TKO), compared to WT ear fibroblasts and is downregulated to a lesser degree in Ripk1 $1^{-/}$Ripk $^{-/-}$Tradd $^{+/-}$cells (Supplementary Fig. 11). We further analyzed in vivo response to TNFa treatment, by intravenous administration in mice. Ripk1 ${ }^{-/-}$Ripk $^{-/-}$Tradd $^{+/-}$ mice displayed a rapid drop in body temperature and succumbed to TNFa-induced shock, similar to WT mice (Fig. 5a, b). However, Ripk1 ${ }^{-1-}$ Ripk $^{-1-}$ Tradd $^{-1-}$ mice and Ripk3 ${ }^{-1-}$ mice did not display a significant drop in body temperature and did not succumb to TNFa-induced shock (Fig. 5a, b).

\section{Discussion}

The TRADD protein was identified almost a quarter century ago, as a potential adaptor molecule for TNFR1 signaling ${ }^{35}$. It was not until the first TRADD KO mice were generated in the year 2008 that the interrogation of the physiological function of TRADD became possible ${ }^{37-39}$. However, Tradd ${ }^{-1-}$ mice show no apparent developmental defect, which is in sharp contrast to the perinatal lethality in $R i p k 1^{-1-}$ mice ${ }^{30}$, and to the mid-gestation lethality in Fadd ${ }^{-1-}$ mice $23,24,26$. Furthermore, Tradd ${ }^{-/-}$mice contain a normal lymphoid compartment, while conditional deletion of RIPK1 or FADD results in T lymphopenia in the periphery ${ }^{31,42}$. These observations appear to indicate TRADD being dispensable during mouse development and lymphocyte development.

Despite having no impact on mouse development, deletion of the necroptosis effector protein kinase RIPK3 completely rescues Fadd ${ }^{-1-}$ mice from embryonic lethality, and the resulting Fadd $^{-1}{ }^{-}$Ripk3 $^{-/-}$DKO mice show progressive lymphoproliferative disease after reaching adulthood ${ }^{29}$. The fact that absence of TRADD is unable to rescue the embryonic defect in Fadd ${ }^{-/}$ mice (Supplementary Fig. 2) indicates that TRADD is dispensable for necroptotic signaling in vivo. Previous studies have indicated a potential role for TRADD in necroptosis, as indicated by Tradd $^{-1-}$ MEFs being resistant to treatment with TNFa, cycloheximide and zVAD (TCZ) ${ }^{38}$. This observation also contrasts the normal embryogenesis in Fadd ${ }^{-1}$ Ripk1 $^{-1-}$ mice $^{26}$. Therefore, necroptosis in embryonic cells is TRADD-independent and occurs directly via RIPK1 in vivo when FADD-mediated apoptosis is inactivated.

Mice lacking the adaptor kinase RIPK1 die shortly after birth, and blocking necroptosis through deletion of the downstream RIPK3, or blocking apoptosis via deletion of FADD provides little survival advantage, because the resulting $\mathrm{Fadd}^{-/} \mathrm{Ripk1}^{-/}$or Ripk1 $1^{-/}$Ripk $3^{-1-}$ DKO mice die within several days after birth $^{26,29,32,33}$. Only when both RIPK3 and FADD are deleted do
Ripk $1^{-1-}$ mice survive to adulthood $29,32,33$. The striking observation in the current study that deletion of TRADD rescues Ripk $1^{-/-}$Ripk $^{-/-}$mice from perinatal lethality (Fig. 1) indicates that TRADD, similar to FADD, may mediate apoptosis in neonatal Ripk1 $1^{-/}$Ripk $^{-/-}$mice and cause perinatal death. Therefore, a lack of phenotype in Tradd ${ }^{-/}$mice is due in part to the presence of RIPK1.

Although both FADD and TRADD mediate apoptosis, functional distinction between these two adaptors is evident. Unlike Ripk $1^{-/-}$Ripk $^{-/-}$Fadd $^{-1-}$ mice, which have normal postnatal development, Ripk1 $1^{-1}$ Ripk3 $^{-/}$Tradd ${ }^{-/}$mice show greatly diminished post-weaning survival (Fig. 1b). The lethality in young adulthood may be explained in part by the severe defect in the intestine in Ripk1 $1^{-/}$Ripk3 $^{-/-}$Tradd $^{-/}$mice (Fig. 1e). The elevated Caspase 3 activation is indicative of enhanced apoptosis in the intestine when both alleles of Tradd are inactivated in Ripk $1^{-/-}$Ripk $^{-1-}$ mice (Fig. 1e). Interestingly, these symptoms are reversed by retaining a single wild-type allele of Tradd in Ripk $1^{-/-}$Ripk $3^{-/-}$mice (Fig. 2), contrasting heterozygosity of FADD which is not sufficient to prevent lethality in Ripk $1^{-/-}$Ripk $^{-/-}$mice during perinatal development ${ }^{29}$. While reducing apoptosis in the intestine, the rescue through haplosufficiency of TRADD did not lead to lymphadenopathy and splenomegaly in the resulting Ripk $1^{-/}$Ripk $^{-/-}$Tradd $^{+/-}$mice (Supplementary Fig. 4), unlike the severe lpr-like symptom in Ripk $^{-/-}$Fadd $^{-/-}$or Ripk1 $1^{-1-}$ Ripk3 $^{-/-}$Fadd $^{-1-}$ mice (Supplementary Fig. 4) ${ }^{29,33}$.

In addition to the intestinal defect, Ripk1 $1^{-1-}$ Ripk3 ${ }^{-1-}$ Tradd $^{-1-}$ TKO mice display severe T lymphopenia (Fig. 3). Interestingly, like in wild-type mice, TKO thymocytes and peripheral mature $\mathrm{T}$ cells are resistant to cell death triggered by TNFa (Fig. 4a and Supplementary Fig. 7,b). However, presence of one allele of wild-type TRADD rendered Ripk1-l-Ripk $3^{-1-}$ thymocytes and mature $\mathrm{T}$ cells hypersensitive to TNFa-induced death (Fig. 4a and Supplementary Fig. 7b, d). In total, the data argue that TRADD indeed mediates TNFa-induced apoptosis in $\mathrm{T}$ cells, when RIPK1 is absent. Therefore, T lymphopenia in the Ripk $1^{-/-}$Ripk $^{-/-}$Tradd $^{-/-}$mice is counterintuitive, given that thymocytes from these TKO mice are completely resistant to TNFa-induced apoptosis. This paradox can be explained in part by the defect in TCR-induced survival and proliferative responses in peripheral mature Ripk1 $1^{-1-}$ Ripk $^{-1-}$ Tradd $^{-1-}$ TKO T cells (Fig. 4b). More importantly, TRADD haplosufficiency, as

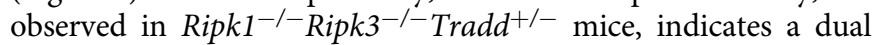
role for TRADD in signaling TCR-induced survival and proliferative responses (Fig. 4b). 
The severely impaired proliferative responses to TCR stimu-

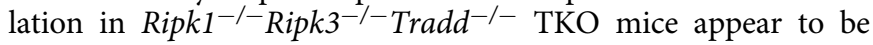
due largely to caspase-dependent apoptosis, because the widespectrum caspase inhibitor zVAD suppressed TCR-induced death in Ripk $1^{-1-}$ Ripk3 $^{-1-}$ Tradd $^{-1-}$ TKO T cells and improved cell division/proliferation (Fig. 4b and Supplementary Fig. 8,b). It is important to iterate that death receptor-induced apoptosis is not affected by deletion of TRADD, as the TKO T cells behave similarly to wild-type $\mathrm{T}$ cells in response to stimulation of Fas and TNFR1 (Fig. 4a and Supplementary Fig. 7a-c). Therefore, the result in Fig. 4b implies a role for TRADD in TCR-induced survival signaling, beyond its role in promoting TNFR1-induced apoptosis as it does in perinatal cells.

One possible explanation for the improved survival of Ripk1 $1^{-/}$Ripk $^{-/-}$Tradd $^{+/-}$cells and mice is the requirement for TRADD in NFKB signaling. Indeed, we found that dermal fibroblasts of adult TKO mice show a complete blockage of TNFa-mediated NFKB signaling as shown by lack of phosphorylation of p65 (Fig. 4d). This indicates that TRADD is essential for NFkB signaling in the absence of RIPK1. Due to the severe defects in the intestines and T cells of TKO mice, there may be a cell type-specific requirement for TRADD-mediated NFKB signaling to prevent apoptosis. Further supporting this notion is the observation that TKO T cells have lower expression of the NFKB targets, cFLIP and Bcl- $\mathrm{X}_{\mathrm{L}}$, as compared with Ripk1--Ripk3 $^{-/-}$Tradd $^{+/-}$or wild-type cells (Fig. 4c). In total, similar to RIPK1 and FADD, TRADD can also initiate or protect against cell death depending on the conditions and cell type.

In summary, the findings in the current study identify a previously unappreciated role for TRADD during perinatal development and in adult mice lacking RIPK1 and RIPK3. Gene dosage of TRADD elicits a Goldilocks effect on the survival of Ripk1 $1^{-/-}$Ripk3 $^{-/-}$mice, whereby Tradd ${ }^{+/+}$and Tradd ${ }^{-/-}$ results in death by apoptosis while haplosufficiency of TRADD proves to be optimal for survival. These findings demonstrate the interplay between cell death and NFKB signaling, identify TRADD as a key component in cell death regulation, and provide insight into the workings of the apoptotic pathway in the presence and absence of RIPK1.

\footnotetext{
Methods

Mice. Both males and females of mus musculus in a C57BL/6 background were used. Tradd ${ }^{-/-}$mice were provided by $\mathrm{Liu}^{38}$. Ripk1 $1^{+/-}$mice were provided by Kelliher $^{30}$. Ripk $3^{-/-}$mice were provided by Newton and Dixit ${ }^{43}$. All mice were bred and housed in a specific pathogen free environment at Thomas Jefferson University. After intercrosses of indicated mice, neonates were monitored daily for survival from birth to weaning age and deceased pups were immediately collected and genotyped. Viable pups were genotyped at weaning age and monitored for survival. Kaplan-Meier survival curves were generated using Prism software (Graphpad Software, Inc.). All animal studies are approved by the Institutional Animal Care and Use Committee (IACUC) at Thomas Jefferson University. For genotyping, DNA was isolated from the ear of mice with an alkaline lysis solution containing $25 \mathrm{mM} \mathrm{NaOH}$ and $0.2 \mathrm{mM}$ EDTA followed by neutralization with 40 $\mathrm{mM}$ Tris- $\mathrm{HCl} \mathrm{pH} \mathrm{5.0.} \mathrm{Allele} \mathrm{specific} \mathrm{primers} \mathrm{were} \mathrm{used} \mathrm{to} \mathrm{amplify} \mathrm{wild} \mathrm{type} \mathrm{and}$ knockout alleles as previously described for Fadd $^{23}$ (WT primers: $5^{\prime}$ - ATG GAC CCA TTC CTG GTG CTG CTG-3'; 5'-CAG TAG ATC GTG TCG GCG CAG CG-3' and KO primers: 5'-ACTGTAGTGCCCAGCAGAGACCAGC - $3^{\prime}$; 5' CGCTCGGTGTTC

GAGGCCACACGC-3'); Ripk1 ${ }^{30}$ (WT\&KO primers: $5^{\prime}$-CTGCTAAAGCGCAT GCTC-3'; 5'-TGTGTCAAGTCTCCCTGCAG-3'; 5'-CACGGTCCTTTTGC CCTG-3'); Tradd $^{38}$ (WT primers: 5'-CACTGACTCTTCAAGACCAGCAGAC-3'; 5'-CAACAGATCCTCTGCTAGACTAGTG-3' and KO primers: 5' -TGCA CATGTGTCCTCGAGTG-3'; 5'-GGAGAGCTTGGCTGTCTTGG-3'); Ripk $3^{43}$ (WT\&KO primers: $5^{\prime}$-CGCTTTAGAAGCCTTCAGGTTGAC-3'; $5^{\prime}$ GCCTGCCCATCAGCAACTC-3'; 5'-CCAGAGGCCACTTGTGTAGCG-3')
}

Embryo analysis. Mating of Fadd ${ }^{+/-} \mathrm{Tradd}^{-/-}$mice was setup in the evening and females were checked in the morning. When vaginal plug was detected, embryos were designated E0.5. Embryos were isolated from pregnant mice at E12.5-E18.5 and genotyped as described above.
Cell culture including fibroblast and $\mathbf{T}$ cell preparation. Thymocytes and peripheral $\mathrm{T}$ cells purified from spleen and lymph nodes were cultured in complete RPMI media (cRPMI) containing 10\% FBS, 2 mM L-Glutamine, penicillin $(100 \mathrm{U} / \mathrm{mL})$, streptomycin $(100 \mu \mathrm{g} / \mathrm{mL})$, and $\beta$-mercaptoethanol $(50 \mu \mathrm{M})$. Fibroblasts were isolated from the ears of euthanized adult mice was adapted from previously established protocol ${ }^{44}$. In summary, ears were sterilized with $70 \%$ ethanol and cut into small pieces. Ear pieces were incubated with warm $0.25 \%$ trypsin at $37^{\circ} \mathrm{C}, 5 \% \mathrm{CO}_{2}$ for $90 \mathrm{~min}$, then broken up and passed through a cell strainer with complete DMEM (cDMEM) containing 10\% FBS, $1 \mathrm{mM}$ L-Glutamine, penicillin $(100 \mathrm{U} / \mathrm{mL})$, streptomycin $(100 \mu \mathrm{g} / \mathrm{mL})$, and $\beta$-mercaptoethanol $(50 \mu \mathrm{M})$ Isolated cells were washed once in CDMEM and cultured on tissue culture-treated plates at $37^{\circ} \mathrm{C}, 5 \% \mathrm{CO}_{2}$.

Histology. Intestines were prepared for histology using the swiss roll technique followed by fixation in $10 \%$ formalin for $24 \mathrm{~h}$. Samples were washed in PBS, placed in $70 \%$ ethanol, and then embedded in formalin. Sections were stained with hematoxylin and eosin or with anti-cleaved caspase 3 antibody (Cell Signaling Technology \#9661).

Flow cytometry. Spleen, lymph nodes, and thymus were isolated during mouse dissection. Bone marrow was isolated from tibias and femurs of mice. Single cell suspension was prepared and red blood cells were depleted by hypotonic lysis. Cells were stained on ice for 30 minutes in PBS containing 3\% BSA, $1 \mathrm{mM}$ EDTA, and $0.05 \%$ sodium azide with fluorochrome-conjugated antibodies anti-CD3 (BD Biosciences, clone 17A2), anti-CD4 (BD Biosciences, clone GK1.5), anti-CD8 (Caltag, clone CT-CD8a), anti-B220 (Caltag, clone RA3-6B2), anti-IgM (Jackson ImmunoResearch, 115-116-075), anti-Macl (BD Biosciences, clone M1/70), antiGr1 (eBioscience, clone RB6-8C5). Samples were washed twice with PBS. Data was acquired on LSR II flow cytometric analyzer (BD Biosciences) and analyzed using FlowJo software (Treestar). Total cell numbers were counted on Countess Automated Cell Counter (Invitrogen) and lymphocyte cellularity was determined by multiplying the total cell number of indicated organ by percentage of $\mathrm{CD}^{+}$or $\mathrm{B} 220^{+}$cells within the organ obtained by flow cytometry.

Cell death assays. Thymocytes $\left(10^{5}\right)$ or purified mature peripheral $\mathrm{T}$ cells were seeded in triplicate in 96 well flat-bottom plates in cRPMI with various concentrations of anti-Fas antibody (BD Biosciences, clone Jo2), mouse TNFa (Alexis Pharmaceuticals), or human TNFa (Life Technologies) for $16 \mathrm{~h}$ with cycloheximide. In indicated experiments, thymocytes were pre-treated with TNFR1 or TNFR2 blocking antibodies (Life Technologies) in complete RPMI on ice for $4 \mathrm{~h}$ before TNFa treatment. Mature peripheral T cells were treated with FLAG-tagged sFasL (Alexis Pharmaceuticals) and anti-FLAG M2 antibody $(1 \mu \mathrm{g} / \mathrm{mL}$, Sigma). After incubation, $1 \mu \mathrm{g} / \mathrm{mL}$ propidium iodide (PI) and the percentage of cell death was analyzed by flow cytometry as determined by $\mathrm{PI}^{+}$cells.

T cell proliferation assays. Mature $\mathrm{T}$ cells were purified of the spleen and lymph nodes by staining with anti-Thy1.2 antibody (BD Biosciences, clone 53-2.1) and sorting Thy $1.2^{+}$cells using a FACS Aria (BD Biosciences). For fluorescent labeling, purified T cells $\left(10^{6} / \mathrm{mL}\right)$ were labeled with $1 \mu \mathrm{M}$ CellTrace ${ }^{\mathrm{TM}}$ Violet in PBS for 20 min at $37^{\circ} \mathrm{C}, 5 \% \mathrm{CO}_{2}$. cRPMI $(5 \mathrm{~mL})$ was added to each tube and incubated for an additional $5 \mathrm{~min}$ at $37^{\circ} \mathrm{C} 5 \% \mathrm{CO}_{2}$. Labeled cells were then centrifuged for 5 minutes, supernatant was removed, and cells were resuspended in cRPMI. Labeled $\mathrm{T}$ cells $\left(2 \times 10^{5}\right)$ were seeded in 96 well round bottom plates pre-coated with $5 \mu \mathrm{g} /$ $\mathrm{mL}$ anti-CD3 (BD Biosciences, clone 145-2C11) in cRPMI with $1 \mu \mathrm{g} / \mathrm{mL}$ anti-CD28 antibodies (BD Biosciences, clone 37.51). At indicated time points, $\mathrm{T}$ cells were collected, $1 \mu \mathrm{g} / \mathrm{mL}$ PI was added, and cells were analyzed by two-color flow cytometry on the LSR II (BD Biosciences) for cell death and division kinetics. Data was analyzed using FlowJo software (Treestar). Caspase activities in purified mature $\mathrm{T}$ cells was measured using CellEvent ${ }^{\mathrm{TM}}$ Caspase 3/7 Green Flow Cytometry Assay Kit (Life Technology), per the manufacturer's instructions. Briefly, T cells were stimulated with $5 \mu \mathrm{g} / \mathrm{mL}$ anti-CD3 and $1 \mu \mathrm{g} / \mathrm{mL}$ anti-CD28 antibodies for the given time points. CellEvent Caspase 3/7 Green Detection Reagent was added to T cell culture, followed by $30 \mathrm{~min}$ incubation at $37^{\circ} \mathrm{C}, 5 \% \mathrm{CO}_{2}$. Samples were immediately run on LSR II cytometer (BD Biosciences) and data analyzed using FlowJo Software (Treestar).

Western blotting analysis. To prepare samples for western blot, single cell suspension of splenocytes was prepared from mice of indicated genotypes to detect the presence or absence of RIPK1, RIPK3, and TRADD. T cells were enriched from the spleen and lymph nodes of mice of indicated genotypes by negative selection using MojoSort Mouse CD3 T cell Isolation kit (Biolegend, \#480031) and stimulated with $5 \mu \mathrm{g} / \mathrm{mL}$ anti-CD3 and $1 \mu \mathrm{g} / \mathrm{mL}$ anti-CD28 antibodies in cRPMI for $16 \mathrm{~h}$ or with $1 \mathrm{x}$ eBioscience Cell Stimulation Cocktail of PMA/Ionomycin (Invitrogen) for $5 \mathrm{~min}$. Fibroblasts were stimulated with $10 \mathrm{ng} / \mathrm{mL}$ TNFa or $1 \mu \mathrm{g} / \mathrm{mL}$ LPS for indicated time points. Cell lysates were prepared in cold RIPA lysis buffer $(50 \mathrm{mM}$ Tris $\mathrm{pH}$ $8.0,150 \mathrm{mM} \mathrm{NaCl}, 1 \%$ Nonidet P-40, $0.5 \%$ deoxycholate, $0.1 \%$ SDS, $1 \mathrm{mM}$ phenylmethyl sulphonyl fluoride (PMSF), and 1X Halt protease inhibitor cocktail (Thermo Scientific). Additional inhibitors were added when probing for phosphospecific proteins $(50 \mathrm{mM} \beta$-glycerophosphate, $1 \mathrm{mM}$ sodium vanadate, $10 \mathrm{mM}$ 
sodium fluoride). Proteins $(40 \mu \mathrm{g})$ were separated on a $10 \%$ SDS-PAGE gel and transferred to a nitrocellulose membrane. Membranes were blocked with $5 \%$ milk in TBST and blotted with antibodies specific for RIPK1 (BD Biosciences, \#610459), RIPK3 (ProSci, \#2283), TRADD (Santa Cruz, sc7868), cFLIP (Alexis Biochemicals, ALX-804-127), Bcl- $\mathrm{X}_{\mathrm{L}}$ (Cell Signaling \#2764), total p65 (Cell Signaling \#3034), or $\beta$-Actin (Sigma Aldrich, A-5441) in 5\% milk in TBST at $4{ }^{\circ} \mathrm{C}$ overnight. For phospho-specific antibodies, membranes were blocked with 5\% BSA in TBST for 1 $\mathrm{h}$ at room temperature and blotted overnight with anti-phosphorylated p65 (Cell Signaling Technology, \#3033) in 5\% BSA in TBST. Membranes were stained with HRP-conjugated secondary antibodies at room temperature for $1 \mathrm{~h}$. Membranes were treated with Western Lightning Plus-ECL (Perkin Elmer, NEL105001EA) and developed using X-Ray film or FluorChem M Western Blot Imaging machine (ProteinSimple). Quantification of signals on X-ray films was performed using the ImageJ software. Uncropped gels are provided in the Source Data file.

TNF $\boldsymbol{\alpha}$-induced shock. Ten micrograms of TNFa (Sino Biological) was injected intravenously into mice. Mice were monitored for survival and core body temperature every $2 \mathrm{~h}$ for $10 \mathrm{~h}$ and at $24 \mathrm{~h}$. Core body temperature was taken with a MicroTherma 2T Hand Held thermometer with rectal probe (Braintree Scientific). Mice were euthanized if moribund or body temperature dropped below $23.6^{\circ} \mathrm{C}$.

Statistical analysis. Data is represented as mean \pm standard error of the mean (SEM). Student's $t$-tests were performed using Prism software (Graphpad Software, Inc.) to determine $p$ value. A $p$ value $<0.05$ was considered significant. Logrank tests were performed to compare survival of various genotypes in Kaplan Meier plots. Chi square analysis was performed to determine significance of genotype tables.

Reporting summary. Further information on experimental design is available in the Nature Research Reporting Summary linked to this article.

\section{Data availability}

The data that support the findings of this study are available within the Article and its Supplementary Information or, on reasonable request, from the corresponding author.

Received: 24 May 2018 Accepted: 18 January 2019

Published online: 11 February 2019

\section{References}

1. Weinlich, R., Oberst, A., Beere, H. M. \& Green, D. R. Necroptosis in development, inflammation and disease. Nat. Rev. Mol. Cell Biol. 18, 127-136 (2017).

2. Nagata, S. Apoptosis and clearance of apoptotic cells. Annu. Rev. Immunol. 36, 489-517 (2018).

3. Strasser, A., Jost, P. J. \& Nagata, S. The many roles of FAS receptor signaling in the immune system. Immunity 30, 180-192 (2009).

4. Nagata, S., Hanayama, R. \& Kawane, K. Autoimmunity and the clearance of dead cells. Cell 140, 619-630 (2010).

5. Ashkenazi, A. \& Dixit, V. M. Death receptors: signaling and modulation. Science 281, 1305-1308 (1998).

6. Boldin, M. P. et al. A novel protein that interacts with the death domain of Fas/APO1 contains a sequence motif related to the death domain. J. Biol. Chem. 270, 7795-7798 (1995).

7. Chinnaiyan, A. M., O’Rourke, K., Tewari, M. \& Dixit, V. M. FADD, a novel death domain-containing protein, interacts with the death domain of Fas and initiates apoptosis. Cell 81, 505-512 (1995).

8. Kischkel, F. C. et al. Cytotoxicity-dependent APO-1 (Fas/CD95) associated proteins form a death-inducing signaling complex (DISC) with the receptor. EMBO J. 14, 5579-5588 (1995)

9. Zhang, J. \& Winoto, A. A mouse Fas-associated protein with homology to the human Mort1/FADD protein is essential for Fas-induced apoptosis. Mol. Cell. Biol. 16, 2756-2763 PMC231266 (1996).

10. Boldin, M. P., Goncharov, T. M., Goltsev, Y. V. \& Wallach, D. Involvement of $\mathrm{MACH}$, a novel MORT1/FADD-interacting protease, in Fas/APO-1-and TNF receptor-induced cell death. Cell 85, 803-815 (1996).

11. Muzio, M. et al. FLICE, a novel FADD-homologous ICE/CED-3-like protease, is recruited to the CD95 (Fas/APO-1) death-inducing signaling complex. Cell 85, 817-827 (1996).

12. Nagata, S. \& Tanaka, M. Programmed cell death and the immune system. Nat. Rev. Immunol. 17, 333-340 (2017).

13. Wallach, D., Kang, T. B. \& Kovalenko, A. Concepts of tissue injury and cell death in inflammation: a historical perspective. Nat. Rev. Immunol. 14, 51-59 (2014).
14. Vanden Berghe, T., Linkermann, A., Jouan-Lanhouet, S., Walczak, H. \& Vandenabeele, P. Regulated necrosis: the expanding network of non-apoptotic cell death pathways. Nat. Rev. Mol. Cell Biol. 15, 135-147 (2014).

15. Holler, N. et al. Fas triggers an alternative, caspase-8-independent cell death pathway using the kinase RIP as effector molecule. Nat. Immunol. 1, 489-495 (2000).

16. Degterev, A. et al. Chemical inhibitor of nonapoptotic cell death with therapeutic potential for ischemic brain injury. Nat. Chem. Biol. 1, 112-119 (2005).

17. Cho, Y. S. et al. Phosphorylation-driven assembly of the RIP1-RIP3 complex regulates programmed necrosis and virus-induced inflammation. Cell 137, 1112-1123 (2009)

18. He, S. et al. Receptor interacting protein kinase- 3 determines cellular necrotic response to TNF-alpha. Cell 137, 1100-1111 (2009).

19. Zhang, D. W. et al. RIP3, an energy metabolism regulator that switches TNFinduced cell death from apoptosis to necrosis. Science 325, 332-336 (2009).

20. Sun, L. et al. Mixed lineage kinase domain-like protein mediates necrosis signaling downstream of RIP3 kinase. Cell 148, 213-227 (2012).

21. Cai, Z. et al. Plasma membrane translocation of trimerized MLKL protein is required for TNF-induced necroptosis. Nat. Cell Biol. 16, 55-65 (2014).

22. Newton, K. \& Manning, G. Necroptosis and Inflammation. Annu. Rev. Biochem. 85, 743-763 (2016).

23. Zhang, J., Cado, D., Chen, A., Kabra, N. H. \& Winoto, A. Fas-mediated apoptosis and activation-induced T-cell proliferation are defective in mice lacking FADD/Mort1. Nature 392, 296-300 (1998).

24. Yeh, W.-C. et al. FADD: essential for embryo development and signaling from some, but not all, inducers of apoptosis. Science 279, 1954-1958 (1998).

25. Varfolomeev, E. E. et al. Targeted disruption of the mouse caspase 8 gene ablates cell death induction by the TNF receptors, Fas/Apol, and DR3 and is lethal prenatally. Immunity 9, 267-276 (1998).

26. Zhang, H. et al. Functional complementation between FADD and RIP1 in embryos and lymphocytes. Nature 471, 373-376 (2011).

27. Oberst, A. et al. Catalytic activity of the caspase-8-FLIP(L) complex inhibits RIPK3-dependent necrosis. Nature 471, 363-367 (2011).

28. Kaiser, W. J. et al. RIP3 mediates the embryonic lethality of caspase-8deficient mice. Nature 471, 368-372 (2011).

29. Dowling, J. P., Nair, A. \& Zhang, J. A novel function of RIP1 in postnatal development and immune homeostasis by protecting against RIP3-dependent necroptosis and FADD-mediated apoptosis. Front. Cell. Dev. Biol. 3, 1-12 (2015).

30. Kelliher, M. A. et al. The death domain kinase RIP mediates the TNF-induced NF- $\mathrm{B}$ signal. Immunity 8, 297-303 (1998).

31. Dowling, J. P., Cai, Y., Bertin, J., Gough, P. J. \& Zhang, J. Kinase-independent function of RIP1, critical for mature T-cell survival and proliferation. Cell Death Dis. 7, e2379 (2016).

32. Rickard James, A. et al. RIPK1 regulates RIPK3-MLKL-driven systemic inflammation and emergency hematopoiesis. Cell 157, 1175-1188 (2014).

33. Dillon Christopher, P. et al. RIPK1 blocks early postnatal lethality mediated by Caspase-8 and RIPK3. Cell 157, 1189-1202 (2014).

34. Kaiser, W. J. et al. RIP1 suppresses innate immune necrotic as well as apoptotic cell death during mammalian parturition. Proc. Natl Acad. Sci. USA 111, 7753-7758 (2014).

35. Hsu, H., Xiong, J. \& Goeddel, D. V. The TNF receptor 1-associated protein TRADD signals cell death and NF-kappa-B activation. Cell 81, 495-504 (1995).

36. Hsu, H., Shu, H.-B., Pan, M.-G. \& Goeddel, D. V. TRADD-TRAF2 and TRADD-FADD interactions define two distinct TNF receptor 1 signal transduction pathways. Cell 84, 299-308 (1996).

37. Ermolaeva, M. A. et al. Function of TRADD in tumor necrosis factor receptor 1 signaling and in TRIF-dependent inflammatory responses. Nat. Immunol. 9 , 1037-1046 (2008)

38. Pobezinskaya, Y. L. et al. The function of TRADD in signaling through tumor necrosis factor receptor 1 and TRIF-dependent Toll-like receptors. Nat. Immunol. 9, 1047-1054 (2008).

39. Chen, N. J. et al. Beyond tumor necrosis factor receptor: TRADD signaling in toll-like receptors. Proc. Natl Acad. Sci. USA 105, 12429-12434 (2008).

40. Pobezinskaya, Y. L. \& Liu, Z. The role of TRADD in death receptor signaling. Cell Cycle 11, 871-876 (2012).

41. Lewis, M. et al. Cloning and expression of cDNAs for two distinct murine tumor necrosis factor receptors demonstrate one receptor is species specific. Proc. Natl Acad. Sci. USA 88, 2830-2834 (1991).

42. Zhang, Y. et al. Conditional Fas-associated death domain protein (FADD): GFP knockout mice reveal FADD is dispensable in thymic development but essential in peripheral T cell homeostasis. J. Immunol. 175, 3033-3044 (2005)

43. Newton, K., Sun, X. \& Dixit, V. M. Kinase RIP3 is dispensable for normal NFkappa Bs, signaling by the B-cell and T-cell receptors, tumor necrosis factor receptor 1, and Toll-like receptors 2 and 4. Mol. Cell. Biol. 24, 1464-1469 (2004). 
44. Khan, M. \& Gasser, S. Generating primary fibroblast cultures from mouse ear and tail tissues. J. Vis. Exp. https://doi.org/10.3791/53565 (2016).

\section{Acknowledgements}

We thank Dr. Zhenggang Liu for providing Tradd ${ }^{-1-}$ mice, Drs. Kim Newton and Vishva Dixit for Ripk3 ${ }^{-/-}$mice, and Michele Kelliher for Ripk $1^{+/-}$mice; Josh Kingman, Nelisa Bechtel, and Luke Arcona for technical help, William A. Foss, Xuhua Zhang and Sarah Jahfali for critical reading of the manuscript, and the technical staff at Flow Cytometry Facility, Research Animal Facility, Metaomics Facility, and Histopathology Facility of the Sidney Kimmel Cancer Center for their assistance, which are supported by NCI Core grant (P30 CA056036). Publication is made possible in part by support from The Thomas Jefferson University + Philadelphia University Open Access Fund. This study is supported in part by NIH grant 1R01AI119069 to J.Z.

\section{Author contributions}

Conceptualization, J.Z.; Methodology, J.Z. and J.P.D.; Investigation, J.P.D., M.A., and C.D.; Writing - Original Draft, J.P.D. and J.Z.; Writing - Review \& Editing, J.Z., J.P.D., M.A., and Z.L.; Funding Acquisition, J.Z.; Resources, J.Z., J.P.D., and Z.L.; Supervision, J.Z.

\section{Additional information}

Supplementary information accompanies this paper at https://doi.org/10.1038/s41467019-08584-5.
Competing interests: The authors declare no competing interests.

Reprints and permission information is available online at http://npg.nature.com/ reprintsandpermissions/

Journal peer review information Nature Communications thanks Daniel Gray and the other anonymous reviewers for their contribution to the peer review of this work.

Publisher's note: Springer Nature remains neutral with regard to jurisdictional claims in published maps and institutional affiliations.

\section{(c) (1)}

Open Access This article is licensed under a Creative Commons Attribution 4.0 International License, which permits use, sharing, adaptation, distribution and reproduction in any medium or format, as long as you give appropriate credit to the original author(s) and the source, provide a link to the Creative Commons license, and indicate if changes were made. The images or other third party material in this article are included in the article's Creative Commons license, unless indicated otherwise in a credit line to the material. If material is not included in the article's Creative Commons license and your intended use is not permitted by statutory regulation or exceeds the permitted use, you will need to obtain permission directly from the copyright holder. To view a copy of this license, visit http://creativecommons.org/ licenses/by/4.0/.

(C) The Author(s) 2019 